\title{
A Disarray Around the Theme of Lesson Planning: Definition and Characterization of its Constituent Elements
}

\author{
Milena Alves \\ Amadeu Moura Bego \\ Brazil \\ Brazil
}

This paper aims to investigate the different meanings that the constituent elements of lesson planning have assumed in the works of Science Education and proposes, from a critical approach, the delimitation of its essential constituent elements, as well as their definitions. To this end, a systematic literature review was performed, involving the analysis of 403 papers from: Science Education journals in strata A1 and A2; Proceedings of Teaching and Education meetings; and theses and dissertations from the CAPES catalog. Studies were selected from 2012 to 2016. An absence of terminological equivalence was found for the terms strategy, methodology, method, technique, and resource. In addition, most of the papers use these terms unlinked from their definitions and any theoretical frameworks. Subsequently, theoretically grounded definitions were proposed for each of the terms in the context of lesson planning. It is argued that the methodological approach guides the teaching and learning process and consists of an essential element of lesson planning, which involves explaining the background conceptions about teaching and learning, the nature of science, and the social role of school education. Therefore, planning a lesson needs to be an explicit and conscious act of the teacher, in which he becomes aware of the methodological approach to be adopted. This approach will guide the requirement for the delimitation of learning objectives, the selection and arrangement of instructional and assessment strategies, as well as the teaching resources and instructional materials.

Keywords: instructional strategy; methodology; teaching resources; method; technique.

\section{The constituent elements of lesson planning}

Lesson planning practices of teachers are sometimes focused on setting instructional activities and/or conceptual content. Besides this, these are based on one single textbook and, generally, in the lesson planning designs, the learning objectives are implicit or not clearly stated (Sánchez Blanco, \& Valcárcel Pérez, 1999; Ustra, \& Hernandes, 2010).

However, nowadays, the teacher's planning act is conceived of as an important trigger for educational innovations (Menegolla, \& Sant'Anna, 2014). This understanding places the lesson planning practice in a fundamental position in the teaching and 
learning process, because it is conceived of as a dimension responsible to define the teacher's work, as well as a reflexive and continuous action of the teacher that involves methodological and theoretical choices (Farias, Sales, Braga, \& França, 2011; Bego, 2013).

In this context, Amaral (2006) lists the elements that composes a good lesson plan, such as: content, method, technique, and teaching resources. Anastasou and Alves (2004), in turn, point out methodologies, strategies, and instruments as constituent elements of lesson plans. Sanmartí (2002) points out objective delimitation and time distribution as important constituent elements of a lesson plan. Finally, Libâneo (2013) cites goals, contents, methods, organizational modes, and assessment as essential constituent elements.

As noted, there are different approaches concerning the constituent elements of a lesson plan. However, different authors considered some elements as being fundamental. Therefore, some planning elements are considered as basic ones, like: objectives and content, methodology, instructional strategies, teaching resources, and assessment strategies (Amaral, 2006; Anastasiou, \& Alves, 2004; Castro, Tucunduva, \& Arns, 2008; Farias et al., 2011; Libâneo, 2013; Piletti, 2004).

Nevertheless, the search for these terms and conceptions in an education database returns some divergences and polysemic conceptualizations. In addition, it is observed that diversified terms have been used with the same meaning. In the literature, there are distinct terms with different senses referring to the same object (Farias et al., 2011; Leal, 2005; Delizoicov, \& Angotti, 1992). For instance, Farias and colleagues (2011) classify lectures, mock juries, debates, and the likes as instructional strategies. However, Leal (2005) defines these same activities as teaching methodologies. Moreover, Delizoicov and Angotti (1992) use these exact words as instructional techniques.

This fact agrees, for example, with Vieira and Vieira's (2005) statement regarding the diffuse use of the term instructional strategy. According to the authors, the term strategy "has been used in multiple contexts, realities, and with a lot of meanings" (p.15). The authors state that, in the context of education, the term strategy is associated to many synonyms, such as: approach, activity, skill, method, model, technique, and tactic.

The polysemic and indistinct use for terms of lesson plan constituent elements is also a concern of Araujo (2012). The author warns that "there is a diversity of ways of using the term teaching methodology in educational research" (p. 25).

The information presented above highlights the large number of conflicting definitions and the noncritical use of terms referring to constituent elements of a lesson plan, indicating little concern with their meanings within a coherent theoretical framework.

Vygotsky (2009), in the context of the development of psychology in the early twentieth century, highlighted the need for clarity and terminological equivalence for some areas of knowledge. According to the author, "the misconception begins in the terminological inaccuracy" and, after that, "a great deal of misunderstandings, because 
academics discuss about different objects but name them by a same word" (p. 422). The author argued that the use of decontextualized expressions generates divergences between the intended meaning and the assigned meaning in a field of study. Therefore, the consolidation of a concept depends on the establishment of relationships and derivations with other concepts in a specific theoretical framework.

Thus, this paper intends to contribute to the area of Science Education, proposing critical and grounded definitions to the constituent elements of lesson plans. This objective is justified, as presented, because the use of decontextualized expressions can generate many divergences between the intended meaning and the assigned meaning in a particular field of study. This can make the line of research regarding lesson planning difficult to consolidate, as well as the production of state-of-the-art work on the subject.

Among different kinds of literature review, the systematic review is a method that can boost a search by increasing the number of results in an organized way. Costa and Zoltowski (2014) list some advantages regarding systematic literature reviews: i) they are neither a chronological and simple list of papers nor a descriptive and linear discussion on a theme, they need to be, in fact, critical and reflexive works; ii) they gather critical evaluation of published works by identifying relationships, contributions, gaps, and inconsistences within a research theme, as well as pointing out suggestions to solve some problems; iii) they minimize the risk of a biased search, because a researcher can just choose articles that confirm his own prior hypotheses by doing a traditional literature review.

In view of the above, this theoretical and bibliographical paper aims to do a systematic review on the different meanings that the constituent elements of a lesson plan have assumed in the area of Science Education. Then, from a critical approach, this work proposes the delimitation of the essential constituent elements of the lesson plan, as well as their conceptual definitions.

\section{Methodological procedures}

This is a theoretical and bibliographical research that aims to present qualitative and quantitative results of a systematic literature review on the meanings of some lesson plan elements, as well as to propose their conceptual definitions in a theoretically grounded framework.

The Content Analysis (CA) method was used based on the principles established by Bardin (2016). The author defines the CA as:

A set of techniques of communication analysis aiming to generate indicators (either quantitative or not) by objective and systematic description procedures of messages which allow the inference of some knowledge regarding the conditions of production/ reception of these messages (Bardin, 2016, p. 48).

Brazilian Science Education journals in strata A1 and A2 were selected in order to conduct the systematic literature review, because these journals are considered the best ones by the CAPES (Brazilian Federal Foundation for Support and Evaluation of 
Graduate Education) Qualis. The Qualis is a set of procedures used by CAPES to stratify the quality of the intellectual production of the Brazilian graduate programs and it is based on the information sent by these graduate programs to CAPES, year by year. Its function is to help the evaluation boards to analyze and classify the bibliographical production of professors and graduates allocated in graduate programs certified by CAPES (Barradas Barata, 2016). The data reflect the highlighted journals in which professors and graduates have published their work. The evaluation criteria used are the journal index, scope, and Google Scholar h5 index and its median (Araújo-Jorge, Borba, \& Sovierzoski, 2016).

Therefore, despite the broad discussion about the indicator build process (Barradas Barata, 2016), but recognizing that the Qualis is a set of procedures used officially by CAPES and legitimated by the academic community, the search was conducted in the Science Education journals classified in strata A1 and A2.

The search for the journals' strata was conducted in the CAPES website called "Plataforma Sucupira", based on the evaluation quadrennium of 2013-2016, specifically in the evaluation area classified as "Teaching".

In the A1 strata, 145 results were found including different education subject journals. From these results, the Brazilian journals called "Ciência e Educação (C \& E)" and "Ensaio-Pesquisa em Educação em Ciências" were selected because they publish studies focused on Science Education. In the A2 strata, 198 results were found. Among them, just 12 were journals whose scope were focused on Science Education. The 12 journals selected were: Revista Brasileira de Ensino de Ciência e Tecnologia (RBECT); Revista Brasileira de Pesquisa em Educação em Ciências (RBPEC); Revista de Educação, Ciências e Matemática (RECM); Revista de Ensino de Ciências e Matemática (REnCiMa); Investigações em Ensino de Ciências (IENCI); Acta Scientae; Alexandria; Amazônia Revista de Educação em Ciências e Matemática; Areté- Revista Amazônica de Ensino de Ciências; Dynamis; Praxis; and Vidya. Particularly, Physics, Mathematics, and Health Education journals were not selected because of the strictness of their scope.

Additionally, the search for proceedings of both Science Education and Education meetings was carried out in order to investigate how the terms were used by the broad scientific community. This search is justified by the relevance of these meetings, because of both the increase in the number of studies submitted and the participation growth of scientific community in the last years. These facts may indicate that the research submitted to these meetings are the result of a wide dissemination of the knowledge generated in the scientific academy and, therefore, may point out possible trends in the use of these terms. The Brazilian meetings analyzed were: Associação Nacional de Pós-Graduação e Pesquisa em Educação (ANPED), Encontro Nacional de Pesquisa em Educação em Ciências (ENPEC), and Encontro Nacional de Didática e Práticas de Ensino (ENDIPE). Lastly, the search was extended to the CAPES Catalog of Theses and Dissertations.

The terms used for the search were chosen by an AC technique called "floating 
reading", which, according to Bardin (2016), is a step that "consists in contacting the research document and recognizing the text, allowing it to invade our impressions and directions" (p. 126). Teaching and Education books and articles regarding lesson planning were used to conduct the floating reading. During the reading of these documents, the most used and the variation of definitions and classifications concerning the targeted terms was observed. Thus, the criteria of choice used was the relevance of the terms to the areas of Education and of Science Education. Besides this, the existence of definitions being incoherent, divergent or even absent was considered. After the floating reading, the terms chosen were: strategy, methodology, method, technique and resource.

As seen, the source and origin of the selected studies were diverse. Due to the large number of articles to be analyzed, 5 years were delimited as a time interval (2012 to 2016) in order to verify how the terms were currently used in these documents.

The terms were searched in the title and keywords of the selected documents from different databases. The search in the C \& E, Ensaio, RBPEC, IENCI journals and in the meeting proceedings and CAPES Catalog was carried out from November 2016 to January 2017 during a master research realized from 2016 to 2018. In the other journals, the search was carried out in 2019 in order to amplify the literature review.

After the systematic review, theoretically grounded definitions were proposed for each of the terms in the context of lesson planning. The definitions were proposed based on the procedures defined by Rios (2006): searching for the etymological origin of the terms, followed by their meaning in the dictionary, and, lastly, their meaning in both a broad context and in the educational context. The interest was effectively to find the way that the terms were used in the field of education, as well as defining "what are the implications of their use and how we can avoid distortions, both in the theoretical configuration and especially in social practice" (Rios, 2006, p. 67).

\section{CA results for the searched terms}

The search for the terms (strategy, methodology, method, technique, and resource) resulted in 403 papers which were analyzed based on CA principles. In the Tables 1 and 2 , there are data about the paper distribution according to source and year of publication.

Table 1. Quantitative paper distribution in the searched period (to be continued)

\begin{tabular}{ccc}
\hline Database & Available papers & Selected papers \\
CAPES & C $^{*}$ & 54 \\
C\&E & 390 & $7(1.80 \%)$ \\
ENSAIO & 227 & $10(4.40 \%)$ \\
IENCI & 210 & $10(4.76 \%)$ \\
RenCiMA & 151 & $7(4.64 \%)$ \\
RBPEC & 207 & $10(4.83 \%)$ \\
RBECT & 190 & $24(12.6 \%)$
\end{tabular}

\footnotetext{
* The number of papers available on the Capes Journal Portal is undetermined, as the website does not provide this information.
} 
Table 1. Quantitative paper distribution in the searched period (continuation)

\begin{tabular}{ccc}
\hline Database & Available papers & Selected papers \\
\hline RECM & 130 & $6(4.62 \%)$ \\
ACTA SCIENTAE & 221 & $11(4.98 \%)$ \\
AMAZÔNIA & 83 & $2(2.41 \%)$ \\
ARETÉ & 227 & $25(11.0 \%)$ \\
DYNAMIS & 56 & $4(7.14 \%)$ \\
PRAXIS & 114 & $16(14.0 \%)$ \\
VIDYA & 120 & $7(5.83 \%)$ \\
ALEXANDRIA & 153 & $3(1.96 \%)$ \\
ANPED & 192 & $10(5.20 \%)$ \\
ENPEC & 3280 & $111(3.38 \%)$ \\
ENDIPE & 4736 & $86(1.82 \%)$ \\
\hline
\end{tabular}

Source: Prepared by the authors.

Table 2. Quantitative paper distribution according to source and year of publication

\begin{tabular}{lccccc}
\hline \multirow{2}{*}{ Type of paper } & $\mathbf{5 0 1 2}$ & $\mathbf{2 0 1 3}$ & $\mathbf{2 0 1 4}$ & $\mathbf{2 0 1 5}$ & $\mathbf{2 0 1 6}$ \\
\cline { 2 - 6 } & 24 & 28 & 25 & 31 & 36 \\
Journal article & 0 & 10 & 12 & 5 & 18 \\
Dissertation & 0 & 0 & 2 & 4 & 3 \\
Theses & 30 & 46 & 35 & 64 & 30 \\
Meeting proceedings & & & &
\end{tabular}

Source: Prepared by the authors.

From the data, it is possible to indicate that the lesson planning theme and its constituent elements have been discussed poorly by the area of Science Education. One possible reason for this is the wide spectrum of research themes and focuses that has been investigated in the last years. As highlighted in the report of Teaching area (AraújoJorge, Borba, \& Sovierzoski, 2016), there has been an increase in the number of graduate programs, as well as in the number of published papers. The report states that:

In November 2016, the Teaching Area had a total of 148 graduate programs present through all regions of the country. The second densest area within the multidisciplinary area and the biggest percentage of professional master programs (51\%). In December 2016 , ten new master programs were approved by CAPES ( 2 academics and 8 professionals), which have not been integrated into this analysis yet, but has increased the area to 158 graduate programs (Araújo-Jorge, Borba, \& Sovierzoski, 2016, p. 4).

However, Villani, Dias and Valadares (2010), analyzing the development of the Science Education research in Brazil, discuss that the institutionalization process of the area can be divided into three phases: the birth and initial setting; the flourishing process; and the growth of a wide number of lines of research. In each of these phases, according 
to the authors, the emphasis in some themes was observed, such as: misconceptions and conceptual change, the role of History and Philosophy of Science, along with studies involving the differences between teachers and researchers. Thus, it is possible to state that, through out the development of the research area, some themes were more widely discussed and, therefore, they are more consolidated. When compared to these traditional lines of research, it is possible to indicate that the lesson planning theme does not have the same amount of papers published and, because of this, it is a theme that is less investigated by the scientific community.

As for qualitative terms, the investigation of the selected work was focused on the term definitions and/or the theoretical reference cited by the authors. The results are discussed case by case next. However, it is worth highlighting that only in $10.4 \%$ of the total number of selected documents, definitions and references for the targeted terms were found.

The most used term was strategy found in 35\% of the total number of works, followed by the term methodology (27.6\%), resource (26.8\%), method (8.9\%), and technique (1.7\%). As the term strategy was the most cited, it may be the most popular term in the context of lesson planning that has been used by those authors and, thus, it has been consolidated among researchers of the area. However, this also may indicate a conceptual and terminological problem, because a lot of works may use the term strategy for referring to any teaching action.

Only $17.7 \%$ of the papers that used the term strategy presented its definition and literature reference. Among the papers that presented references, the follow authors were cited: Beluce (2012); Luckesi (1994); Manzini (2010); Masetto (2012); Morin (2005); Petrucci and Batiston (2006); and Sant'Anna and Menegolla (2011).

These authors, in general, understand strategy as procedure sequences, as ways used by teachers to articulate the teaching and learning process, and as steps followed by teachers after the definition of learning objectives. In this sense, instructional strategies are responsible for enabling the learning objectives and they are understood as intentional and planned actions, as a set of actions elaborated based on an objective, as a set of ways used by the teacher to facilitate student learning, and, finally, as actions that take place during instruction and assessment.

The analyzed papers classified the following as instructional strategies: solving exercises and problems; pair/group activities; directed studies; document, film, and video analysis; simulations; debates; hands-on activities; illustrations; text production and discussion; seminars; dialogues; teaching model elaborations; use of software and concept maps. This type of classification agrees with the classification of Farias and colleagues (2011) for the term instructional strategies. The authors define strategies as a teaching scaffolding that allows the interactivity between teacher, students and knowledge. They classify the following list as being strategies: lectures, mock juries, debates, seminars and others.

The second most discussed term in the analyzed works was methodology, which 
was presented in 111 papers. However, only $5.40 \%$ of these works presented definitions and references. The adopted references were Manfredi (1993) and Haydt (2006). These works assumed teaching methodology as different ways to teach the content, as different strategies used in the teaching and learning process, and as ways to reach a learning objective.

Only one paper presented a definition to the term methodology, but without any reference. This paper defined methodology as instructional procedures used by teachers aiming to create favorable conditions to the teaching and learning process.

Analyzing what kind of activities were classified as teaching methodologies by the authors, the following list was found: use of video, music, blog and game; and seminars and workshops. In other works, however, the authors classified as teaching methodologies: problem-based learning; the inquiry-based learning; and the three pedagogical moments. The first group of authors presents an idea about methodology related to actions developed during instruction, i.e., methodology is understood in the same sense as strategy, as conceived by Farias and colleagues (2011). Nonetheless, the other group of authors understands methodology as the teacher's conceptions about teaching and learning, in other words, their conceptions about what learning is and how teaching should be conducted.

The term resource was the third most discussed. It was the term for which less divergences were found. The following list is classified as teaching resources: games; simulators; scientific dissemination materials; books; data projector; blackboard and chalk; and other objects.

Only 8 (7.40\%) of 108 documents presented a definition for teaching resource. One paper used Castoldi and Polinarski (2009) as references. They define teaching resource as the materials that help the student to learn. Other works cited the following references: Sant'Anna and Sant'Anna (2004), Libâneo (2013), Zabala (1998) and Góes (2002). Briefly, these authors understand teaching resources as a set of materials that help teachers to interact with students; as learning instruments; and as ways to help teachers to solve specific teaching and learning problems.

The term method was used in 36 documents. Among them, only 3 works (8.33\%) brought a referenced definition to the term. The term method was defined as a "way that conducts to a goal". Method was the term that presented the greatest amount of divergences in classifications and definitions. In the same paper, sometimes the author used strategy as synonymous with method, and at other times, they used method as synonymous with methodology. Among all the papers, $6 \%$ used the term without either any definition or distinction. One possible reason for this is that the term was used without any reference, i.e., the term was used based on its popularization and common meaning.

The less used term in the papers was technique. This finding may indicate that this is the least popular term used in the area of Science Education. Seven papers that used the term were analyzed, however, none of them presented any definition or classification 
concerning what was being considered as a technique.

To sum up, many terminological conflicts were observed and, in the majority of the papers, the terms used for the lesson plan elements were used based on their popularization and, therefore, without any reference from their field of study. Thus, it is clearly necessary to conduct research in order to propose terminological equivalences and definitions for these terms.

Based on this, in the next section, critical discussion and proposals for the five terms are presented to contribute to the development of research in the area of Science Education.

\section{Definition proposal for the constituent elements of lesson plans}

This section aims to present a critical reflection regarding the definitions and meanings that have been used to designate the constituent elements of lesson plans. To do this, as discussed previously, the etymological origin of the terms was researched, as well as their dictionary meaning, and their meaning both in a broad context and in the education context.

The first term to be discussed is strategy. Its etymological origin is from the Greek words stratos and agein, which means, respectively, army and command. For this reason, the first definition refers to the action of commanding an army (Martins, 1984).

The dictionary meaning of strategy is also related to army terminology and presents the following definition:

S. f. 1. Planning for an army to execute movements and operations of troops, ships and/ or airplanes, aiming to reach or keep relative positions and favorable war potential for future tactical actions on specific objectives. 2. Army art to choose where, when and who to fight a battle. 3. Art of applying available ways to reach specific goals. 4. Art of exploring favorable conditions aiming to reach specific goals. 5. Stratagem (Ferreira, 2009, p. 835).

Martins (1984), in the army context, argues that a strategy must be flexible and contain equally viable alternative solutions that can lead to the intended ends, allowing corrections required in the course of events.

In the area of education, diverse definitions are observed for this term. Farias and colleagues (2011), as argued, define strategy as scaffolding that allows and sustains the interaction between students, teacher, and knowledge. The authors justify this definition because the strategies, similarly to the scaffolding, are necessary to organize and allow a safe and organized teacher action in classroom. Henning (1998) understands strategy as a way to trigger the teaching process, aiming to develop scientific performances and allowing learning goals to be reached. Delizoicov and Angotti (1992), in turn, conceive that the instructional strategies and techniques are not equal to teaching methodologies but are part of them.

Thus, for a better understanding of the meaning of strategy, a very fruitful way is to present its differences from and approximations to the term methodology. 
The etymological definition of the term methodology comes from the Greek words methodos, i.e., meta that means objective, goal; hodos that means way, intermediation; and logia that means knowledge, study.

In the dictionary, methodology is defined as:

S. $f$. 1. The art of driving the spirit to the investigation of the truth. 2. Study of methods and, specially, science methods: methodology of natural science. 3. Set of techniques and processes used to exceed the author's subjectivity and to reach the literary work (Ferreira, 2009, p. 1322).

Araujo (2012), in the context of education, designates methodology as the structural element that drives what can and needs to be done, that is, a guiding and prescriptive dimension of the pedagogical work. Moreover, the author describes methodology as a theoretical and practical dimension, i.e., it cannot be practiced without thought, as well as its not being thought of outside the context of practice. Amaral (2006) agrees with this understanding about methodology as a structural dimension of lesson planning, responsible for shaping strategies, resources, and assessments.

On the other hand, Leal (2005) states that methodology is the "set of methods applied to a teaching situation" (p. 4) and complements that, to avoid a pedagogical sameness, a teacher needs to recognize that "there is a methodological diversity that can be used in the classroom and/or teaching situation" (p. 5). From this understanding, the author classifies as teaching methodologies the following list: exposition; group work; directed study; seminar; and individualized learning.

Interestingly, this latter understanding of methodology is very close to that of instructional strategy and contrasts with the understanding of methodology as a structuring dimension of planning.

The understanding of Fisher (1978) on methodology, in turn, is related to the idea of an articulation between a theory of interpretation of reality and a specific practice. In this sense, the methodological dimension of lesson planning, within the scope of Science Education, is related to the following: a grounded theory about systematic action at school, involving psychological and pedagogical conceptions about the teaching and learning process; the objectives of school education; a view of the nature of science; and roles of teachers and students in the educational process.

The teaching methodology is, as such, responsible to shape and guide the other constituent elements of lesson plan. This conception agrees with the definitions of Araujo (2012) and Amaral (2006), otherwise it disagrees with the perspective presented by Leal (2005).

Therefore, from this broad review, this paper argues that the meaning of teaching methodology is that close to its etymological origin; that is, related to the meaning of path, in the sense of study of methods. In this approach, it is understood that a teacher does not change her/his beliefs about teaching and learning at different times and activities in the context of the classroom, but she/he has such a methodological conception, explicit or implicit, which guides her/his way of acting inside the classroom. So, a teacher does 
not use different methodologies to teach a particular subject, but she/he has a particular methodological tendency that drives her/his action in the classroom.

From this definition, it is possible to classify the following as teaching methodologies, specifically in the scope of Science Education: traditional education (Cachapuz, Praia, \& Jorge, 2002); discovery-based learning (Cachapuz, Praia, \& Jorge, 2002); inquiry-based learning (Carvalho, 2013); the three pedagogical moments (Delizoicov, \& Angotti, 1992); the Science, Technology and Society (STS) approach (Santos, \& Mortimer, 2002); Problem-Based Learning (PBL) (Ribeiro, 2005); and others.

After defining methodology, its differences in relation to strategy are discussed. Vieira and Vieira (2005) use the term instructional strategy as a set of teacher-oriented actions, aiming to promote the development of skills in students. Anastasiou and Alves (2004), in turn, understand strategy as the application of different means to achieve meaningful learning.

It is interesting to note that, for the authors, the instructional strategies are related to the actions developed by the teacher to achieve the learning objectives. This is the same understanding of Farias and colleagues (2011) and Henning (1998). This approach agrees with the meaning of the dictionary and with the proposition of Martins (1984) for the term strategy, which define strategy as solutions capable of achieving established goals.

In this understanding, this paper proposes that instructional strategies are a set of planned and intentional actions, aiming to achieve learning objectives. They are, therefore, intrinsically flexible and are equally conditioned by the teacher's beliefs. In addition, instructional strategies are chosen, in the scope of formal planning, from the definition of learning objectives. Thus, they are not equal to methodologies.

On the flexible characteristic of instructional strategies, Amaral (2006) points out:

For instance, despite our efforts, when we use a lecture to problematize a theme or to develop a critical and diverse thought in students, a lecture will never reach the same efficiency of a debate or a simulation. The inverse reasoning is true: if our intention is to finalize a subject or a rigorous transmission of notions and concepts, a debate will never be as good as a lecture (Amaral, 2006, p. 4).

The author claims that, although instructional strategies can be shaped by some methodological teaching approach, it is only possible to change their secondary characteristics, since if there is a change in their primary characteristics, they lose their recognizable proprieties and become other instructional strategies.

Another important aspect about instructional strategies is that they do not have a biunivocal relationship with objectives, because some cases require more than one instructional strategy to reach a particular learning objective. On the other hand, the same instructional strategy can be used at different times in order to achieve different learning objectives (Sánchez Blanco, \& Valcárcel Perez, 1993). The intentionality of a strategy will be determined both by the phase of the teaching sequence (opening, development, application or conclusion) and by the methodological approach adopted. 
From the definition and characteristics presented, instructional science strategies can be classified as the following: the use of experimental activities (Giordan, 1999); the use of concept maps (Moreira, 2006); the use of case studies (Sá, Francisco, \& Queiroz, 2007); the use of didactic games (Cunha, 2012); the use of models, analogies, and metaphors (Monteiro, \& Justi, 2000); the use of the history and philosophy of science (Loguercio, \& Del Pino, 2006); the event-based learning (Cruz, 2001); and others.

The term technique is now analyzed and critically discussed. Its etymological origin comes from the Greek words $\tau \dot{\chi} \chi \nu \eta$ and téchne which refer to a set of rules to reach something.

The search for the meaning of the term in the dictionary returned the following definition:

S. f. 1. The material part or set of processes of an art: surgical technique, legal technique.

2. Special way or skill to execute something: this student has his own technique of study.

3. Practice (Ferreira, 2009, p. 1925).

In the context of education, Araujo (2012) defines instructional technique as activities developed in schools and as a particular way of acting that contains guidelines aimed at student learning.

Anastasiou and Alves (2004) define instructional techniques as a set of processes in an art and as special ways of doing something. The authors understand that technique is a synonym of strategy. Nevertheless, they chose to use the term instructional strategy because they compare a teacher's work to that of a strategist, i.e., a work that must consider the constraints of real-life scenarios of each school. In turn, Delizoicov and Angotti (1992) use these two terms as synonymous, but they defend the use of technique instead of strategy. Unfortunately, they don't justify this choice.

Based on these meanings and definitions, this paper argues that the terms instructional strategy and technique, within the scope of Didactics, are not the same as teaching methodology, but they are understood as a set of actions planned by the teacher in order to achieve specific learning objectives. There is therefore agreement with Anastasiou and Alves (2004) and Delizoicov and Angotti (1992) and it is understood that technique and instructional strategy are synonymous, as they have similar meanings in the context of Didactics.

Nonetheless, in this paper, it is suggested that the adoption of the term instructional strategy be preferred over technique, for the following reasons:

1) The definition of the term defended by most authors and the meaning of the dictionary for technique is a "special way or ability to do something", "a particular way of doing something". This kind of meaning can imply that there is only one fixed and correct way of doing something and, therefore, a technique is always ready and complete. A technique would be a way of doing something that would be applied equally anywhere and would always achieve the same results;

2) To associate the term instructional technique with the conceptual model of 
teaching presented by the literature as a model of technical rationality (Bego, 2016). This association may imply some refuted teaching practices, characterized by the literature as technical pedagogy, insufficient and inadequate to cover the complexity of the teaching activity and the school environment;

3) Because of the small number of works published in the area of Science Education that use the term instructional technique and the results of the systematic literature review carried out in this paper, it was seen that the term has the lowest frequency of use, suggesting that it is currently the least popular term in the area. On the contrary, the term instructional strategy has the highest frequency of use in the area;

4) Because it is possible to compare a teacher's work with that of a strategist, that is, a work that involves study, selection, arrangement, and proposition of flexible actions in order to reach particular learning goals. But these actions must be adapted to the complexities, uniqueness and multifaceted realities of teaching scenarios (Anastasiou, \& Alves, 2004; Bego, 2016).

Finally, the term teaching method is discussed. This term presented the largest number of conceptual and terminological conflicts in the analyzed studies. The etymological origin of the term comes from the Greek words methodos, meta (objective, goal), and hodos (way), i.e., a way forward to reach a goal.

The search for the term in the dictionary returned the follow definition:

S. m. 1. A way forward to reach a goal. 2. Program that priorly regulates a series of operations which must be done, pointing out avoidable errors in order to achieve a specific result. 3. Teaching process or technique: directed method. 4. Way of proceeding; way of acting. 5. Media. 6. Elemental treatment. 7. Fig. Prudence, circumspection; judicious way of proceeding; order: always acts with method (Ferreira, 2009, p. 1322).

In general literature, it was found that method is a set of systematic activities that allow a goal to be reached (Marconi, \& Lakatos, 2011). In the field of Didactics, Veiga and colleagues (1992) presented the following definition: "the method brings within it the idea of a direction that aims to achieve a purpose. It is not any kind of construction, but one that leads you to achieve a specific purpose certainty" (p. 84). The authors list three teaching methods: traditional method, intuitive method, and active method. These teaching methods have distinct characteristics regarding the roles of both teachers and students and the understanding of teaching and learning.

In the same direction, Farias and colleagues (2011) define teaching method as a set composed by assumptions, principles, and procedures that help the pedagogical work, containing conceptual and operational elements that allow the concretization of educative practice. For the authors, teaching methods and teaching methodologies are very similar terms.

Amaral (2006) defines teaching method as a path to a specific end. However, 
for the author, teaching methodology and teaching method are not synonyms, because "the methods are the paths of the teaching and learning process, determining the very content of the message that is being transmitted" (p. 5). In addition, the author says that "teaching methods articulate and concretize their forms of use [referring to other constituent elements of lesson plans], coherently composing a teaching methodology approach" (p. 8).

Given the above, it can be inferred that teaching method is not synonyms with instructional strategy and technique, because method incorporates them. A teaching method is a set of articulated activities that compose a certainty way toward a learning purpose. Consequently, a teaching method is inherently formed by assumptions and principles that guide a teacher's activity in the classroom, composing a directed way of acting. Because of this understanding, a teaching method would not be as flexible as instructional strategies.

Another important aspect to be discussed is with respect to the relationship between teaching method and teaching methodology. From the understanding of Farias and colleagues (2011) and Veiga and colleagues (1992), the terms teaching method and methodology are considered synonyms. Nevertheless, based on Amaral (2006), Fisher (1987), and the etymological origin of the term methodology, it is possible to identify an important difference between teaching methodology and method.

The word methodology is formed by the Greek suffix "logia" strongly related to the dimension of the study of the methods, i.e., methodology is related to the idea of a theory of interpretation and comprehension of reality which will guide and ground the pedagogical practice. In turn, the term teaching method, as pointed out by Amaral (2006), would compose the concrete dimension of the path proposed and developed by the teacher, formed by the articulation and arrangement of strategies and resources in a given teaching situation.

Therefore, this paper proposes that the term teaching method is not exactly the same as teaching methodology, because methodology is better related to a theoretical plane involving conceptions regarding teaching and learning. A methodology has a social character in terms of the theoretical propositions of teaching approaches based on specific conceptions, principles and premises. However, a method has a concrete character, involving an adaptation of a methodological approach by a teacher in a given teaching situation. Contrary to methodology, a teaching method has a markedly personal character.

Figure 1 shows a schematic of the interrelationships of all the concepts discussed thus far. This schematic highlights the characteristics and relationships established between the constituent elements of lesson plans and the pedagogical practice of teachers, according to the definitions proposed in this paper. 


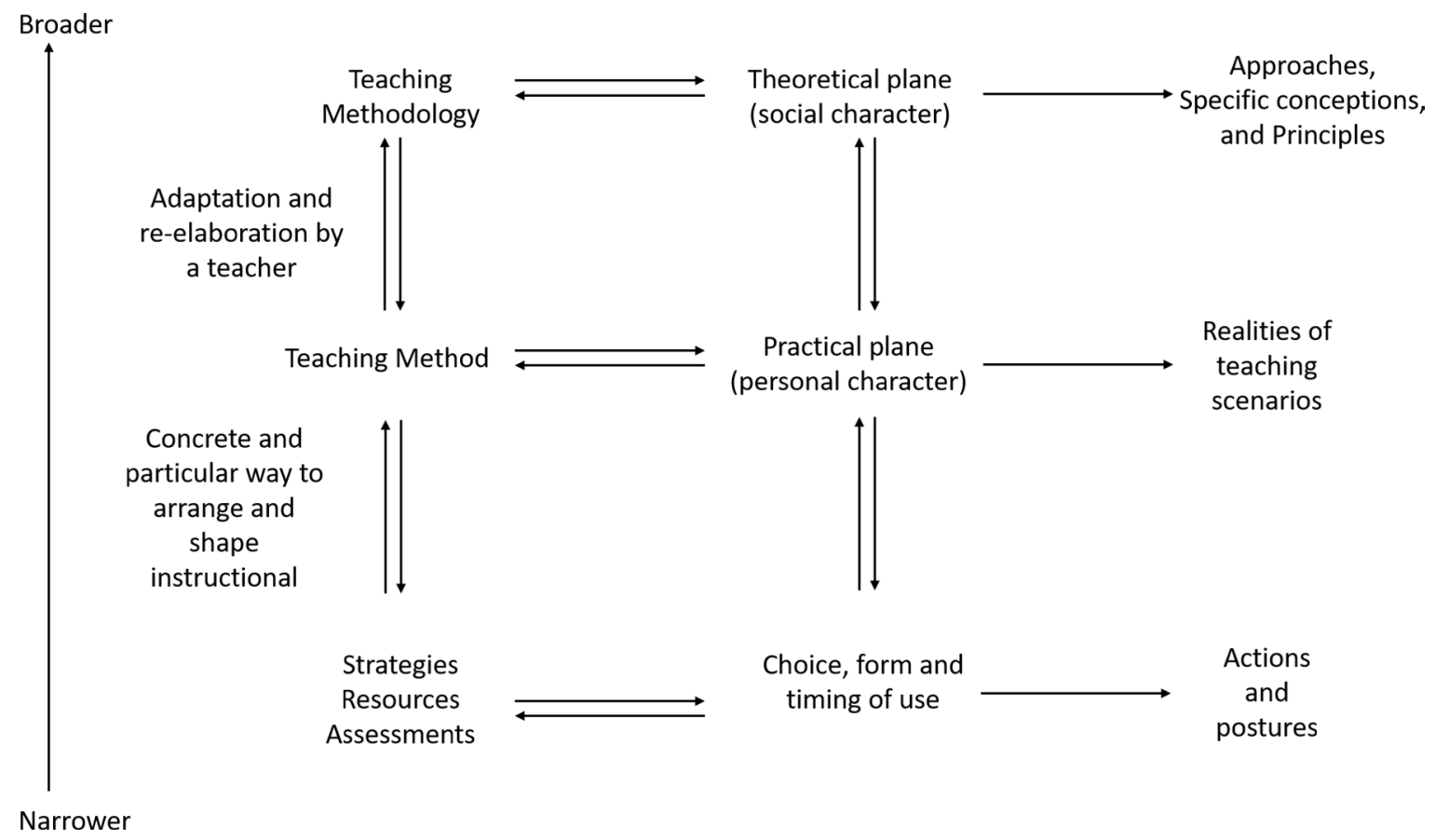

Figure 1. Characteristics and relationships between the constituent elements of lesson plans and the pedagogical practice of teachers

Source: Prepared by the authors.

In the Figure 1, the double arrows indicate the interrelationships between the lesson planning elements and represent the influence of the adaptations that elements experience from the theoretical traditions and the practical constraints in which they are found. It is important to point out that the arrows are not intended to represent any intensity of the relationships, but rather the movement of influence and the interrelationship between all the elements that make up a lesson plan.

As noted, a teaching methodology is in a theoretical plane and is related to strategies, because it theoretically guides the criteria of strategy selection and arrangement. In turn, a teaching method is in a practical plane, because it is a concrete and particular way for each teacher to arrange and shape instructional strategies and resources. It is also noted that teaching methodology is the broadest element of a lesson plan and that all planning elements (methodology, method, strategy, resource, and assessment) are interrelated.

It is noteworthy that there is a dialectical tension between the theoretical plane and the practical plane. The former has a social character and the latter has a personal character, because the methodological teaching approach drives the choice and arrangement of the other planning elements. However, the theoretical proposals for teaching methodological approaches are also influenced by established traditions in the field of practice. Therefore, theory and practice are constantly interrelated.

Based on all these considerations, finally, the term resource is discussed. The etymological origin of this term comes from the Latin word recursus, whose meaning 
is to make the way again. Its meaning in the dictionary is made up of some definitions, such as:

S. m. 1. Effect or act of appealing. 2. Assistance, help, protection. 3. Media, expedient: he used all available resources. 4. Monetary means; cash: he found himself suddenly without any resources to pay his debts. 5. A way to solve a problem; medicine, solution. 6. Legal. Means of provoking, at a similar or superior instance, the reform or modification of an unfavorable judgment. 7. Braz. N. E. V. House of Tolerance. V. resource (Ferreira, 2009, p. 1714).

These definitions refer to the legal context in which a resource is used in order to reform or alter an unfavorable judgment in some instance.

In the educational scope, the term instructional resource is often used. Veiga and colleagues (1992), for instance, argue that:

[...] the resources available to develop the teaching work tend to be considered as simple instruments in a class, thus diminishing their meaning for equipment and objects, although inadequate for the objectives and contents studied (Veiga et al., 1992, p. 41).

Nonetheless, other terms are found, such as: learning materials (Sánchez Blanco, \& Valcárcel Perez, 1993) and curricular materials (Zabala, 1998). Zabala (1998) defines curricular materials as ways of helping teachers to solve problems at different steps of planning, execution, and evaluation. For the author, curricular materials and teaching resources are synonyms.

Farias and colleagues (2011) define instructional resources as media, materials, and instruments that support the action of teachers. Amaral (2006), in turn, defines instructional resources as vehicles of some content.

All these definitions indicate that there are no divergences and disparities in the meanings proposed by the authors, as well as in the meaning of the term in the dictionary, except in the legal scope. This result agrees with results of the systematic literature review presented in the last section. The definitions presented are related to objects and physical media that support activities. In short, depending on the theoretical framework used, all these terms can be considered synonyms.

However, there are some authors who choose to distinguish the terms instructional resources and learning or lesson materials.

In the understanding of these authors, instructional resources are objects or physical media available to be used to support the teacher's activities (Sanmartí, 2002; Sánchez Blanco, \& Valcárcel Perez, 1993). In agreement with these authors, this paper proposes that instructional resources are to be understood as physical means and vehicles of some content that help in the development of instructional strategies, but are not produced by teachers. Consequently, according to this classification, instructional resources can be defined as the following: blackboard, chalk, data projector, overhead projector, periodic table, magazines, newspapers, computers, apps, videos, films, reagents and glassware, among others.

In turn, the learning or lesson materials are understood as materials prepared 
by teachers and/or students to perform specific activities in the classroom, such as: a concept map, an experimental script, an exercise list, a slide show, etc. (Sanmartí, 2002; Sánchez Blanco, \& Valcárcel Perez, 1993). In this sense, both instructional resources and learning materials are directly related to instructional strategies, but they are not synonyms.

Figure 2 shows the synthesis and systematization of the proposed definitions concerning the constituent elements of lesson plans.

\begin{tabular}{|c|c|c|c|}
\hline $\begin{array}{l}\text { Planning } \\
\text { elements }\end{array}$ & Definition of the term & Characteristics & Examples \\
\hline Methodology & $\begin{array}{l}\text { It is every theory about } \\
\text { teaching and learning. It is } \\
\text { related to psychological and } \\
\text { pedagogical conceptions } \\
\text { about learning, the nature of } \\
\text { science, the function of the } \\
\text { regular education system, } \\
\text { and the roles of teachers and } \\
\text { students in class }\end{array}$ & $\begin{array}{l}\text { Covers instructional } \\
\text { strategies, resources, and } \\
\text { assessments. It is located } \\
\text { in a social and theoretical } \\
\text { plane of the planning } \\
\text { developed by the academic } \\
\text { community. It is responsible } \\
\text { to shape and guide all } \\
\text { planning elements }\end{array}$ & $\begin{array}{l}\text { Traditional education; } \\
\text { discovery-based learning; } \\
\text { inquiry-based learning; } \\
\text { the three pedagogical } \\
\text { moment; STS approach; } \\
\text { PBL }\end{array}$ \\
\hline Strategy & $\begin{array}{l}\text { Set of planed and intended } \\
\text { actions of the teacher to } \\
\text { reach learning objectives, } \\
\text { i.e., it is the element } \\
\text { responsible to enable the } \\
\text { desired goals }\end{array}$ & $\begin{array}{l}\text { It is flexible and shaped by } \\
\text { the teaching methodology. } \\
\text { It is defined, in general, } \\
\text { after the delimitation of } \\
\text { objectives }\end{array}$ & $\begin{array}{l}\text { experimental activities; } \\
\text { conceptual maps; case } \\
\text { studies; didactic games; } \\
\text { models, analogies, and } \\
\text { metaphors; history and } \\
\text { philosophy of science; } \\
\text { event-based learning }\end{array}$ \\
\hline Technique & $\begin{array}{l}\text { Set of actions planned by } \\
\text { teachers to reach a particular } \\
\text { learning objective (it can } \\
\text { be considered synonymous } \\
\text { with strategy) }\end{array}$ & $\begin{array}{l}\text { Technique can be associated } \\
\text { to technical pedagogy }\end{array}$ & $\begin{array}{l}\text { The same examples of } \\
\text { strategy }\end{array}$ \\
\hline Method & $\begin{array}{l}\text { Set formed by strategies } \\
\text { and resources based on } \\
\text { assumptions and principles } \\
\text { that guide the teacher's } \\
\text { activity in the classroom }\end{array}$ & $\begin{array}{l}\text { It changes depending on the } \\
\text { teacher's point of view and } \\
\text { purposes. It is in a practical } \\
\text { and personal plane of the } \\
\text { lesson planning }\end{array}$ & $\begin{array}{l}\text { It is particular to each } \\
\text { plan in the school-based } \\
\text { learning environment }\end{array}$ \\
\hline Resources & $\begin{array}{l}\text { Physical means and vehicles } \\
\text { of some content }\end{array}$ & $\begin{array}{l}\text { Support the development } \\
\text { of instructional strategies, } \\
\text { but are not produced by } \\
\text { teachers }\end{array}$ & $\begin{array}{l}\text { blackboard, chalk, data } \\
\text { projector, overhead } \\
\text { projector, periodic table, } \\
\text { magazines, newspapers, } \\
\text { computers, apps, videos, } \\
\text { films, reagents and } \\
\text { glassware }\end{array}$ \\
\hline $\begin{array}{l}\text { Learning } \\
\text { or lesson } \\
\text { materials }\end{array}$ & $\begin{array}{l}\text { Materials prepared by } \\
\text { teachers and/or students to } \\
\text { perform specific activities in } \\
\text { the classroom }\end{array}$ & $\begin{array}{l}\text { Prepared by teachers and/or } \\
\text { students }\end{array}$ & $\begin{array}{l}\text { concept maps, } \\
\text { experimental scripts, } \\
\text { exercise lists, slide show } \\
\text { etc. }\end{array}$ \\
\hline
\end{tabular}

Figure 2. Lesson planning elements, their definitions, characteristics, and classification

Source: prepared by the authors. 
Figure 3 shows a concept map that summarizes the ideas and definitions in this paper, as well as the interrelationships and characteristics of all constituent elements of a lesson plan

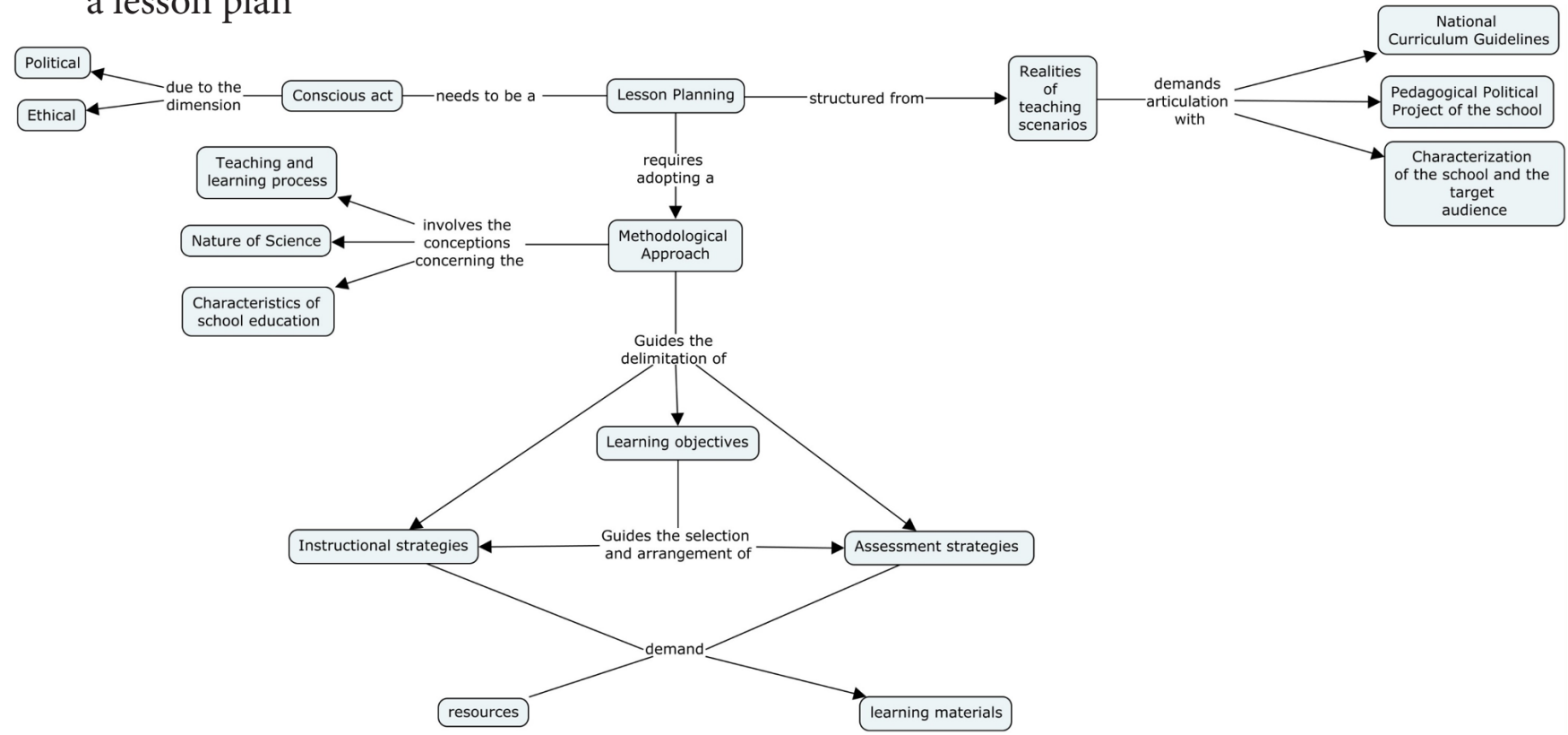

Figure 3. Concept map of the constituent elements of a lesson plan and their arrangements

Source: prepared by the authors.

From the point of view of the act of Science Education planning, it is argued that the methodological approach guides the instruction and consists of the essential element of planning, which involves making explicit conceptions about the teaching and learning process, the nature of science, and the function of school education.

Therefore, it is argued that the teaching planning, much more than a bureaucratic and uncritical activity, is one the most important dimensions in the teacher's work, as it has a political and ethical dimension, as well as puts in question fundamental aspects such as beliefs, ideas, and values that guide the pedagogical practice. In this light, the lesson planning must be a conscious act of the teacher, in which she/he becomes aware of the teaching methodology to be adopted which will guide the delimitation of the learning objectives, as well as the selection and arrangement of strategies, resources and learning materials required.

\section{Final considerations}

This paper discussed the importance of both the planning and the need for a teacher to plan lessons as a conscious act, due to the political and ethical dimension involved. In addition, it was also explained that the lesson planning should occupy a fundamental place in pedagogical practice, because it is responsible for guiding the teacher's work in order to make it a continuous critical and reflexive action.

Besides this, the systematic literature review pointed out the necessity for more grounded and solid definitions for the constituent elements of lesson plans. The elements 
discussed were: methodology, method, strategy, and resource. As noted, the terms have been used disconnected from either any definition or reference. Inconsistencies and indiscriminate use of the terms of planning were observed, for example, the use of teaching methodology and strategy as synonymous.

In view of the above, definitions were proposed for the constituent elements of lesson plans. For this, a search was made for the etymological origin and the meaning in the dictionary of these terms, as well as a search for their meanings in a broader context and, most importantly, in the scope of education.

According to the proposals presented, teaching methodology is the broadest element of planning and involves the conceptions concerning the function of the teaching and learning process, the nature of science, and the characteristics of school education. This element of planning guides and structures other elements such as strategy, technique and resources, because it underlies the delimitation of teaching purposes.

Instructional strategy was defined as a set of actions intentionally planned by the teacher in order to achieve learning objectives. As argued, strategies are defined after the learning objectives are delimited and they may be adjusted and adapted based on the methodological teaching approach. It was proposed that instructional strategy and technique have similar meanings and can be considered synonymous, but the use of strategy was recommended instead of technique.

Teaching method was defined as a set of instructional strategies and resources resulting from the adaptations promoted by the teacher due to the teaching methodology adopted and the school-based learning environment. So, the teaching method is at the practical and personal level of lesson planning.

Instructional resources are the physical means that support and conduct a particular content, but they are not necessarily prepared by teachers. On the other hand, learning or lesson materials are prepared by the teacher and/or students aiming to develop specific teaching activities.

Finally, it is noteworthy to say that this proposal attempts to define the constituent elements of lesson plans and these definitions were based on a theoretical perspective and, therefore, they are not absolute nor immutable. Additional in-depth studies may be undertaken by the academic community to provide a better understanding of the dimensions, characteristics, and elements of lesson plans.

\section{Acknowledgments}

The authors thank the Brazilian Federal Foundation for Support and Assessment of Graduate Education (CAPES) for supporting this research.

\section{References}

Amaral, I. A. (2006). Metodologia do Ensino de Ciências como produção social. Recuperado de: http://docplayer.com.br/12841974-Metodologia-do-ensino-de-ciencias-comoproducao-social-versao-preliminar-ivan-amorosino-do-amaral-maio-de-2006.html 
Anastasiou, L. G. C., \& Alves, L. P. (2004). Processos de ensinagem na universidade: Pressupostos para as estratégias de trabalho em aula. Joinville: Univille.

Araújo-Jorge, T. C., Borba, M. C., \& Sovierzoski, H. H. (2016). Considerações sobre classificação de periódicos. Recuperado de http://http://www.ppgcimes.propesp. ufpa.br/ARQUIVOS/documentos/DOCUMENTO_CRITERIOS_PERIODICOS_ ENSINO_2016.pdf

Araujo, J. C. S.(2012). Do quadro negro à lousa virtual: técnicas, tecnologia e tecnicismo. In I. P. A. Veiga (Org.), Técnicas de ensino: Novos tempos, novas configurações (pp. 1348). Campinas: Papirus.

Bardin, L. (2016). Análise de conteúdo. São Paulo: Edições 70.

Barradas Barata, R. de C. (2016). Dez coisas que você deveria saber sobre o Qualis. Revista Brasileira de Pós-Graduação. 13(30), 13-40. http://dx.doi.org/10.21713/23582332.2016.v13.947

Bego, A. M. (2013). Trabalho escolar e trabalho docente. In A. M. Bego. Sistemas Apostilados de Ensino e Trabalho Docente: Estudo de caso com professores de Ciências e gestores de uma Rede Escolar Pública Municipal (pp. 93-127). (Tese de Doutorado em Educação para a Ciência). Faculdade de Ciências, Universidade Estadual Paulista "Júlio de Mesquita Filho". Bauru.

Bego, A. M. (2016). Políticas públicas e formação de professores sob a perspectiva da racionalidade comunicativa: da ingerência tecnocrata à construção da autonomia profissional. Educação \& Formação, 1(1), 3-24. https://doi.org/10.25053/edufor. v1i2.1864

Beluce, A. C. (2012). Estratégias de ensino e de aprendizagem e motivação em ambientes virtuais de aprendizagem. (Dissertação de Mestrado em Educação). Universidade Estadual de Londrina, Londrina.

Cachapuz, A., Praia, J., \& Jorge, M. (2002). Perspectivas de ensino: caracterização e evolução. Recuperado de https://edisciplinas.usp.br/pluginfile.php/1611805/mod_ resource/content/5/EPTeEPD.pdf

Carvalho, A. M. P. (2013). Ensino de Ciências por investigações: condições para a implementação em sala de aula. São Paulo: Cengage Learning.

Castoldi, R, \& Polinarski, C. A. (2009). A utilização de Recursos didático-pedagógicos na motivação da aprendizagem. In: I Simpósio Nacional de Ensino de Ciência e Tecnologia. (p.684). Ponta Grossa, PR.

Castro, P. A. P. P., Tucunduva, C. C., \& Arns, E. M. (2008). A importância do planejamento das aulas para organização do trabalho do professor em sua prática docente. Athena: Revista Científica de Educação, 10(10), 49-62. 
Costa, A. B., \& Zoltowski, A. P. C. (2014). Como escrever um artigo de revisão de sistemática. In S. H. Koller, M. C. P. P. Couto \& J. V. Hohendorff. (Orgs.) Manual de Produção Científica (pp. 55-70). Porto Alegre, RS: Penso.

Cruz, S. M. S. C. S. (2001). Aprendizagem centrada em eventos: uma experiência com o enfoque Ciência, Tecnologia e Sociedade no ensino fundamental. (Tese de Doutorado em Educação). Centro de Ciências da Educação, Universidade Federal de Santa Catarina, Florianópolis.

Cunha, M. B. (2012). Jogos no ensino de química: considerações teóricas para utilização em sala de aula. Química Nova na Escola, 34(2), 92-98.

Delizoicov, D., \& Angotti, J. A. (1992). Metodologia do Ensino de Ciências. São Paulo: Cortez.

Farias, I. M. S., Sales, J. O. C. B., Braga, M. M. S. C., \& França, M. S. L. M. (2011). Didática e docência: aprendendo a profissão. Brasília: Liber Livro.

Ferreira, A. B. H. (2009). Novo Dicionário Aurélio da língua portuguesa. 4. ed. Curitiba: Ed. Positivo.

Fischer, R. M. B. (1978). A Questão das Técnicas Didáticas: Uma proposta comprometida em lugar da decantada "neutralidade" das técnicas didático-pedagógicas. Ijuí: mimeo.

Giordan, M. (1999). O papel da Experimentação no Ensino de Ciências. Química Nova na Escola, 10, 43-49.

Góes, M. C. R. (2002). Relações entre desenvolvimento humano, deficiência e educação: contribuições da abordagem histórico-cultural. In M. K. Oliveira, D. T. R. Souza, \& T. C. Rego. (Orgs.), Psicologia, educação e as temáticas da vida contemporânea (95-114). São Paulo: Moderna.

Haydt, R. C. C. (2006). Curso de didática geral. São Paulo: Ática.

Henning, G. J. (1998). Metodologia do Ensino de Ciências. Porto Alegre: Mercado Aberto. Leal, R. B. (2005). Planejamento de ensino: peculiaridades significativas. Revista Iberoamericana de Educatión, 37(3), 1-6. https://doi.org/10.35362/rie3732705

Libâneo, J.C. (2013). Didática. São Paulo: Cortez.

Loguercio, R. Q., \& Del Pino, J. C. (2006). Contribuições da história e da Filosofia da Ciência para a construção do conhecimento científico em contextos de formação profissional de Química. Acta Scientiae, 8(1), 67-77.

Luckesi, C. C. (1994). Filosofia da educação. São Paulo: Cortez.

Manfredi, S. M. (1993). Metodologia do ensino: diferentes concepções. Campinas: F. E./ UNICAMP, mimeo.

Manzini, E. J. (2010). Jogos e recursos para comunicação e ensino na educação especial. Marília: ABPEE. 
Marconi, M. A., \& Lakatos, E. M. (2011). Metodologia Científica. São Paulo: Atlas.

Martins, R. F. R. C. (1984). Acerca do conceito de estratégia. Nação e Defesa, 29, 98-125.

Masetto, M. T. (2012). Competência pedagógica do professor universitário. São Paulo: Summus Editora.

Menegolla, M., \& Sant'Anna, I. M. (2014). Por que planejar? Como Planejar? Petrópolis: Vorazes.

Monteiro, I. G., \& Justi, R. S. (2000). Analogias em livros didáticos de química brasileiro destinados ao ensino médio. Investigações em Ensino de Ciências, 52(2), 67-91.

Moreira, M. A. (2006). Mapas conceituais e diagramas V. Recuperado de: http://www. mettodo.com.br/ebooks/Mapas_Conceituais_e_Diagramas_V.pdf

Morin, E. (2005). Introdução ao pensamento complexo. Rio de Janeiro: EuroAmerica. 2005.

Petrucci, V. B. C., \& Batiston, R. R. (2006). Estratégias de ensino e avaliação de aprendizagem em contabilidade. In Peleias, I. R. (Org.) Didática do ensino da contabilidade. São Paulo: Saraiva.

Piletti, C. (2004). Didática Geral. São Paulo: Editora Ática.

Ribeiro, L. R. de C. (2005). Aprendizagem Baseada em Problemas (PBL): uma implementação na educação em engenharia na voz dos atores. (Tese de Doutorado em Educação). Centro de Educação em Ciências Humanas, Universidade Federal de São Carlos, São Carlos.

Rios, T. A. (2006). Competência e Qualidade na docência. In T. A. Rios. (Orgs.) Compreender e ensinar por uma docência da melhor qualidade (pp. 63-92). São Paulo: Cortez.

Sá, L. P., Francisco, C. A., \& Queiroz, A. L. (2007). Estudos de caso em Química. Química Nova, 30(3), 731-739. http://dx.doi.org/10.1590/S0100-40422007000300039

Sánchez Blanco, G., \& Valcárcel Pérez, M. V. (1993). Diseño de Unidades Didácticas em el área de Ciencias Experimentales. Enseñanza de las Ciencias, 11(1), 33-44.

Sánchez Blanco, G., \& Valcárcel Pérez, M. V. (1993). Science Teachers' Views and Practices in Planning for Teachin. Journal of Research in Science Teaching, 36(4), 493-513.

Sanmartí, N. (2002). Didactica de las ciencias en la educación secundaria obligatoria. Madrid: Síntesis.

Sant'Anna, I. M., \& Sant' Anna, V. M. (2014). Recursos educacionais para o ensino: quando e por quê? Petrópolis: Vozes.

Sant'Anna, I. M., \& Menegolla, M. (2011). Didática: Aprender a ensinar. São Paulo: Editora Loyola. 
Santos, W. L. P., \& Mortimer, E. F. (2002). Uma análise de pressupostos teóricos da abordagem C-T-S (Ciência - Tecnologia- Sociedade) no contexto da educação brasileira. Ensaio - Pesquisa em Educação em Ensino de Ciências, 2(2), 110-132. http://dx.doi. org/10.1590/1983-21172000020202

Ustra, S. R. V., \& Hernandes, C. L. (2010). Enfrentamento de problemas conceituais e de planejamento ao final da formação inicial. Ciência \& Educação, 11(3), 723-733. http:// dx.doi.org/10.1590/S1516-73132010000300015

Vieira, R. M., \& Vieira, C. (2005). Estratégias de ensino/aprendizagem. Lisboa: Instituto Piaget.

Veiga, I. P. A., Damis, O. T., Lopes, A. O., Lima, M. E., Castanho, M., Martins, P. L. O., \& Cunha, M. I. (1992). Repensando a didática. Campinas: Papirus.

Vigotski, L. S. (2009). A construção do pensamento e da linguagem. São Paulo: WMF Martins Fontes.

Villani, A., Dias, V. S., Valadares, J. M. (2010). The development of Science Education Research in Brazil and Contribution from the History and Philosophy of Science. International Journal of Science Education, 32(7), 907-937. http://dx.doi. org/10.1080/09500690902855711

Zabala, A. (1998). A prática educativa. Porto Alegre: Artmed.

Milena Alves

https://orcid.org/0000-0002-7867-7877

Universidade Estadual Paulista Júlio de Mesquita Filho Instituto de Química Araraquara, São Paulo, Brazil milena.alves1@unesp.br

Amadeu Moura Bego https://orcid.org/0000-0001-9182-1987 Universidade Estadual Paulista Júlio de Mesquita Filho Instituto de Química Araraquara, São Paulo, Brazil amadeu.bego@unesp.br

Submitted on 1st July 2018 Accepted on 30th December 2019 Published on 21st February 2019 